\title{
Fronteras afectivas de la esfera pública y semiótica pragmática ${ }^{1}$
}

\author{
Cristina Peñamarín ${ }^{2}$
}

Enviado: 15 de mayo 2020 / Aceptado: 4 de junio 2020

Resumen. Se estudia aquí cómo puede una perspectiva semio-pragmática contribuir al estudio de la comunicación pública, de las formas de mediatización y de las condiciones que hacen posible la recepción y el sentido de los asuntos públicos. Se propone un objeto de análisis intermedio, el asunto o problema público, entre la dimensión macro, de las mentalidades y las enciclopedias, y la micro, de las situaciones y textos particulares, pero capaz de conectar ambos niveles. La investigación se centra en el espacio-tiempo de la recepción y en la vinculación entre sentido, imaginación y afecto en la actividad interpretativa.

Palabras clave: mediatización; asuntos públicos; sentido; enciclopedia; espacio-tiempo; afecto; imaginación

\section{[en] Affective frontiers of the public sphere and pragmatic Semiotics}

\begin{abstract}
This work studies how a semi-pragmatic perspective can contribute to the study of public communication, the forms of mediatization and the conditions that make possible the reception and the meaning of public issues. An intermediate object of analysis is proposed, the public issue or problem, between the macro dimension of mentalities and encyclopedias, and the micro dimension of particular situations and texts, but capable of connecting both levels. The research focuses on the space-time of reception and on the link between meaning, imagination and affect in interpretive activity.

Keywords: mediatization; public issues; meaning; encyclopaedia; time; space; affect; imagination.
\end{abstract}

Sumario: 1. El tiempo de la recepción y la forma de los asuntos públicos. 2. Las emociones de los públicos. 3. La circulación del sentido y el afecto. 4. El bloqueo del sentido y las fronteras afectivas. Bibliografía.

Cómo citar: Peñamarín, C. (2020). Fronteras afectivas de la esfera pública y semiótica pragmática, en CIC. Cuadernos de Información y Comunicación 25, 61-75.

Para Wenceslao Castañares, inolvidable colega y amigo.

1 Este artículo se enmarca en el Proyecto I+D "Problemas públicos y controversias: diversidad y participación en la esfera mediática" (CSO2017-82109-R), financiado por el Ministerio de Economía y Competitividad.

2 Universidad Complutense de Madrid

cpberis@ucm.es 


\section{El tiempo de la recepción y la forma de los asuntos públicos}

Sabemos que una democracia requiere un espacio de mediación comunicativa entre representantes políticos y ciudadanía, donde ésta pueda formarse una opinión sobre los asuntos públicos e informarse sobre las actuaciones de los responsables políticos. Requiere lo que llamamos una esfera pública. Sin embargo, ese concepto suele confundir más que aclarar. La dificultad de pensar la esfera pública radica en lo inaprensible, irrepresentable y excesivo de tal objeto. Joseph Gusfield, inspirándose en Goffman, Austin, Perelman, Jakobson, sostenía que "entender el lenguaje como acción es crucial para interpretar el teatro de la vida pública" (1981:22). Y propuso observar la construcción de los problemas públicos en trabajos seminales en los que analizaba, por ejemplo, "cómo los "hechos" sobre el alcohol y la conducción se transforman en el problema público del alcohol y la conducción" (Gusfield 1981: 54, comillas del autor). Parte de aquí una perspectiva semio-pragmática que trata de observar la esfera pública "en su hacerse", a partir del estudio de la construcción de asuntos o problemas públicos, su proceso de definición, discusión, publicitación, resolución, como un proceso que construye, al tiempo que un asunto público, la propia esfera pública (Cefaï, 2002; Peñamarín 2018). Esa EP, hoy más compleja y enredada que nunca, surge, en esta hipótesis, de la selección, definición y tratamiento, por parte de diferentes actores y medios, de cierto número de asuntos convertidos en objetos de atención pública.

Me propongo aquí atender al modo en que esa perspectiva semio-pragmática puede contribuir al estudio de ese ámbito central de la comunicación pública. Y de la vida política que, según Arendt, atañe al "mundo común" de "objetos y asuntos que construimos" entre todos (1997: 118). ¿Cómo conocemos, comprendemos y sentimos ese mundo común en el que participamos? Al poner el foco de indagación en un objeto o asunto, la esfera pública resulta mucho menos inaprensible y gaseosa. Aparece entonces claramente delimitado lo que se puede decir, lo que no se puede decir y lo que es obligatorio decir o sentir respecto a tal asunto. Podemos observar la esfera pública porque un sector de ella resulta objetivado, materializado, en los lugares comunes de la expresión y del contenido, en los argumentos y discursos manifestados en las diferentes perspectivas sobre el asunto en cuestión. Así mismo, se van concretando en el desarrollo del asunto como problema común, los actores, las voces, los intereses, los medios, las redes, que participan en esa materialización de la esfera pública.

Nuestra pregunta clave es cómo puede el público informarse de un problema y entenderlo; qué información, qué conocimiento, qué sistemas de sentido y qué lugares comunes circulan en ese espacio público y cómo afectan al desarrollo del problema. Recogemos de la perspectiva pragmática -de Peirce, James, Dewey, Mead (Castañares 2009)-, al menos dos propuestas: en primer lugar, entendemos que hablar del sentido requiere que nos acerquemos al punto de vista del receptor, el intérprete, el público. Y, en segundo lugar, adoptamos también la máxima pragmática de observar el conocimiento a partir de sus consecuencias. Cuando nos preguntamos por el conocimiento público sobre un asunto nos encontramos de nuevo ante un objeto inaprensible, salvo que observemos sus consecuencias, es decir, qué entra y qué no entra en el espacio público, qué resulta objetivado en el debate sobre tal asunto; cómo condiciona el voto, la adhesión a determinado partido o posición política y en qué sentido (algo hoy públicamente conocido gracias a las numerosas encuestas e 
investigaciones de opinión, de intención de voto, etc., con que contamos). Porque "la esfera pública no la forman sólo los medios o los espacios de interacción pública. Es el repositorio cultural / informacional de ideas y proyectos que alimentan el debate público" (Castells, 2008).

Acercarnos al punto de vista del receptor implica tener en cuenta su forma de vida y en particular la temporalidad, las prácticas y hábitos de comunicación inscritos en su vida cotidiana. En esa cotidianeidad del receptor, muy mediatizada, se introducen muy distintas informaciones cada día o cada hora, pero la sucesión de los días trae consigo la reiteración de múltiples temas, imágenes, marcos de sentido y discursos. La información de la actualidad fragmenta, minimiza el contexto espacial y temporal más amplio de cada asunto, para presentar un panorama o un mosaico de acontecimientos seleccionados y restringidos a su supuesta relevancia en el presente. Pero este presentismo es construido con rutinas, marcos, lugares comunes, reiterados durante décadas, que no pueden no dejar huella en los discursos comunes y en la memoria de los públicos. Por ello, hemos de pensar en efectos de sentido que incluyen los modos del presentismo y la fragmentación en el tiempo largo de la cultura, la enciclopedia, los hábitos y el sentir del receptor. Observar este tipo de efecto de sentido, que pasa a menudo desapercibido, requiere tener en cuenta la continuidad del tiempo de vida, así como el entrelazamiento de pensamiento y afecto. Como dice Williams, "No el sentimiento contra el pensamiento; sino pensamiento como sentido y sentimiento como pensamiento: conciencia práctica presente en una continuidad vivida e interrelacionada" (Williams, 1977, p. 133. Traducción nuestra, C.P.)

Resulta evidente que no habría esfera pública sin medios de comunicación. Pero ¿qué hacen los medios? Como dice Belting respecto a la imagen, "un medio es forma, o transmite la forma misma en que percibimos las imágenes" (2015: 155). En cada caso hemos de observar la mediatización como un problema formal, atender a la forma en que el medio hace percibir, entender y sentir el asunto. Ciertamente, en nuestra "civilización de la imagen", nada es informativamente relevante sin imágenes y algunos asuntos acceden a los medios debido a la capacidad de impacto de las imágenes con las que se asocian. Los medios moldean o modulan (Simondon 2015: 59-60) los asuntos públicos por medio de recursos material-simbólicos que realizan la conexión entre los ámbitos de la producción y la recepción y conforman el sentido de los textos que difunden. En este trabajo de mediación participan diversos actores (profesionales, políticos, sociales, institucionales) con competencias, programas y fines diferentes (Latour, 1991), entre los que nos interesan particularmente los fines de los propios medios de comunicación, su objetivo fundamental de llamar y retener la atención de su audiencia. Al centrar nuestra mirada en el issue o asunto en cuestión, optamos por un objeto de análisis intermedio, entre lo macro de las mentalidades, las enciclopedias, las estructuras, y lo micro de las situaciones o textos particulares, pero capaz de conectar ambas dimensiones. Si tomamos series o secuencias de textos e intercambios referidos a un asunto, podemos observar el desarrollo de "la carrera del problema público" (Gusfield, 1981) en ciertos medios y para ciertos públicos, así como las pugnas o acuerdos entre las perspectivas y los intereses en juego que se manifiestan en las controversias, objeto de particular interés en esta investigación.

El punto de vista del público aparece en los textos gracias al mecanismo omnipresente en la comunicación del feedback. Quien comunica trata siempre de anticipar los intereses y supuestos de su destinatario. Los públicos de los medios, hoy segmentados por soportes, generaciones, orientaciones políticas, estéticas, etc., son bien 
conocidos por sus respectivos emisores. La atención de esos emisores está puesta constantemente en el feedback de su público, al que trata de "fidelizar", así como en su posibilidad de alcanzar audiencias mayores. Proliferan los estudios de opinión y las técnicas de seguimiento de los usos y preferencias de los públicos, como de cualesquiera potenciales consumidores. En el mercado de audiencias y consumidores, la dificultad y el interés están en que no siempre los públicos reaccionan como los emisores habían previsto. La identidad de los públicos puede ser tan precaria e inestable como la de los sujetos que los componen. Sin embargo, en este mundo incierto y cambiante, parecen hacerse deseables las certezas y se percibe en los medios una constante estabilización de lugares comunes, de hitos de referencia compartidos, de imaginarios que se reiteran sin cesar creando sentidos obvios e incontestados, que son centrales en este estudio.

Las constituciones democráticas reconocen el derecho a la libertad de expresión, aunque, paradójicamente, no siempre explicitan el derecho a la información por parte de la ciudadanía. Y hoy no parece clara la diferencia entre lo que es (buen) periodismo y lo que no lo es. Aunque se da por supuesta la necesidad de la información pública para el buen funcionamiento de la democracia, se hacen borrosos los criterios que definen el pacto social que rige las expectativas de los receptores acerca de la actividad periodística (Escudero, 1996), aquejada de una falta de confianza y credibilidad por parte de los públicos (Gitlin, 2003; Álvarez, 2014). Por ello, tan necesario es comprender las consecuencias de los actuales procesos de mediatización, como reconocer la necesidad de la crítica y reconstrucción de los valores del periodismo, así como de un sistema público de información que haga posible la discusión y elaboración de los problemas comunes garantizando la participación de las diferentes perspectivas interesadas. La diversidad de perspectivas es tan fundamental para la democracia que, según Arendt (1993: 66-67), sólo hay esfera pública cuando hay una pluralidad de visiones sobre un asunto. Y sin embargo, como veremos, a menudo tales visiones encontradas no llegan a plasmarse en una controversia que haga avanzar la elaboración pública del problema.

\section{Las emociones de los públicos}

Si queremos preguntarnos cómo se construyen las emociones de los públicos hemos de indagar cómo da el público sentido a lo que percibe y cómo eso le puede afectar, lo que implicará observar cómo se conforman y articulan las dimensiones cognitiva, imaginativa y afectiva de la interpretación. No es posible desarrollar aquí, ni apenas esbozar, una teoría de los sentimientos o un método para su análisis. Sólo puedo dar algunas indicaciones en este sentido. Sabemos que todas las culturas elaboran poemas, relatos, imágenes, dichos, formas de saber común (aunque desigualmente repartido) sobre las emociones. E igualmente en todas las sociedades surgen pautas, "reglas del sentir" (Hochschild, 1990), según las cuales cada persona orienta y juzga sus propias emociones y las de los demás. Todo lo que sabemos, o creemos saber, de las emociones interviene en la forma que les damos y el modo en que las vivimos.

Se suelen entender los afectos como parte de una naturaleza humana universal a la que se añade lo sociocultural como un segundo momento, generalmente empobrecido (Leys, 2011) (como puede verse a menudo en neurociencia, psicología y buena 
parte de los Affect Studies). Aquí no discutiré acerca de la cualidad afectiva inscrita en la biología, la naturaleza, de muchos seres vivos (es posible que el sistema afectivo sea tan esencial para la supervivencia de esos seres como el sistema digestivo). Lo que me importa señalar es que esta cualidad afectiva muestra al humano como un ser relacional y sensible, capaz de reaccionar en cada momento a su entorno material y social y a su lugar en él. Las emociones son constitutivamente relacionales. Cada experiencia afectiva (emocional, sentimental o pasional, términos que de momento no distinguiré) es una experiencia de afectar y ser afectado, incluso no conscientemente, en modos agradables o desagradables, de sentirse participar en cuanto nos sucede en el contacto con todo lo otro. Cada experiencia se da en un entorno, circunstancia y relaciones particulares, en los que surgen afectos positivos o negativos (Gross, 2006) en un sujeto no vacío, sino dotado de una vida anterior, de un saber y una memoria corporeizada. Las experiencias dejan huellas que impregnan y conforman nuestra memoria corporal, afectiva y semiótica (nuestra enciclopedia -Eco, 1990) y, a su vez, hacen participar a esa memoria en la reacción corporal y en la interpretación que en cada momento da sentido a esa experiencia.

Esa disposición a reaccionar afectivamente a todo lo otro es continua y permanente en la criatura humana. Afirma el neurobiólogo Damasio

Pocas percepciones de cualquier objeto o acontecimiento, si acaso alguna, presente realmente o recordada a partir de la memoria, son neutrales en términos emocionales. Ya sea a través de designio innato o por aprendizaje, reaccionamos a la mayoría de objetos, quizá a todos, con emociones, por débiles que sean, y con los sentimientos posteriores, por tenues que sean. (Damasio, 2006: 92)

Las emociones desafían desde siempre la capacidad humana de comprensión porque nos obligan a pensar la imbricación entre la emoción impensada, que nos "prende" o nos "asalta", y los sistemas de sentido y valor gracias a los cuales podemos actuar sobre esa emoción, pensarla, elaborarla, como un "sentimiento" ya nombrado y conocido, que diría Damasio. Pero ni siquiera en esa emoción primera hay sólo espontaneidad, en ella intervienen la memoria y los "hábitos emocionales". Quien está acostumbrado a cazar o a vivir bajo las bombas tiene una reacción ante el sonido de un disparo o de una explosión muy diferente de quien no ha conocido esas experiencias y no tiene ese hábito que modula las sensaciones de susto o de miedo de quienes están familiarizados. Y lo mismo han documentado sobre la reacción instintiva de asco los estudios de Elias (2009) y Miller (1998). Los hábitos emocionales, que operarían en buena parte fuera de la percepción consciente, proveen a sus miembros con una "disposición emocional, un sentido de qué y cómo sentir, etiquetas para sus formas de sentir, esquemas acerca de lo que son y de lo que significan, modos de comprender lo que sienten" (Gould, 2009: 34). En las emociones intervienen inseparablemente cuerpo y mente, naturaleza y artificio, reacción instintiva y cultura de los afectos.

Si toda percepción está afectada emocionalmente en mayor o menor grado, como sostiene Damasio, todo encuentro o comunicación también lo está, se trate de un encuentro con un texto, una situación, un objeto o con otro ser; sea un encuentro mediado o no mediado. Como señalan Macón y Solana, los afectos intervienen en la articulación de la experiencia (2015: 17) y de las formas en que le damos sentido y valor. "Los afectos son aquello que une, lo que sostiene o preserva la conexión entre 
ideas, valores y objetos" (Ahmed 2004: 8). No son sólo estados psicológicos, implican también prácticas sociales y culturales, hábitos y enciclopedias, fundamentales para producir la superficie y los límites entre lo interior y lo exterior, la frontera entre yo y los otros, entre lo individual y lo social, como dice Ahmed (2004:10). Sin que deje de haber en el sentir receptividad, capacidad de reaccionar, también implica la capacidad de responder. Los afectos actúan, por ejemplo, alterando con su irrupción la esfera pública (Macón y Solana, 2015: 18), y seguramente inducen a actuar, a adoptar unas u otras actitudes.

Esa afectividad se denuncia hoy a menudo como hipertrofiada en los medios. Se afirma incluso que las emociones están redefiniendo la concepción clásica de la objetividad periodística y la idea de noticia, ya que se hace cada día más claro y explícito el uso de las emociones para tratar de implicar a la audiencia en los discursos informativos (Beckett and Deuze, 2016). No sorprende que ciertas investigaciones entiendan los medios como "generadores de afecto" (affect generators, Lünenborg and Maier, 2018; Reckwitz, 2017). Junto a la experiencia de conocer algo del mundo de un modo más o menos "fiable", los medios proporcionan a su público la experiencia de participar, implicándose afectiva y valorativamente, en los acontecimientos. De ver su propia opción política alentada, argumentada, confirmada, por su medio favorito, el que han elegido por su afinidad con su visión del mundo, al tiempo que el respeto a las reglas del discurso periodístico permiten a cada receptor considerar su perspectiva como legitimada por el fair play de su medio y defendible como neutral (Peñamarín, 2014).

Muchas investigaciones aportan interesantes observaciones sobre los relatos y marcos que se promueven, los lugares comunes de la expresión o del contenido que son objetivados en los mensajes y discursos de la esfera pública. Pero, de cara a integrar la dimensión afectiva de los textos, hemos de tener en cuenta que indagar el sentido afectivo de algo implica observar dónde está el sujeto-yo en ese cuadro, qué me importa, cómo me afecta a mí, receptor. Hemos de integrar esa perspectiva en el estudio de las emociones que se crean y difunden colectivamente y que podemos observar tal como quedan cristalizadas en los textos y en los lugares comunes que circulan públicamente en un momento y lugar particulares. Esto no hace más fácil pensar sobre las emociones, siempre un objeto espinoso, pero nos lleva a enfocar ciertos aspectos particulares de este amplio campo.

En el ámbito de las construcciones semióticas que implican un tiempo largo, ciertos marcos de sentido y valor se han revelado extraordinariamente eficaces para movilizar y configurar las emociones de amplios públicos (pensemos en la guerra de Irak (2003-2011), por no tomar más que este ejemplo ya clásico (ver Lakoff, 2007: 70; Arsenaut y Catells, 2006:289; Butler, 2006: 61). Son encuadres o estructuras de sentido que aúnan lo semántico, lo imaginativo y lo afectivo, emoti-marcos, que logran situar a su destinatario (a cada yo), y a amplias colectividades de ellos, en el seno de un mundo de sentido y valor (acertado o no, orientado a un futuro temible o deseable, es otra cuestión sin duda clave en la vida política). De entrada, sabemos que ubican a cada persona en un ámbito en el que se despeja la incertidumbre y cada quien sabe qué quiere, qué odia, tiene claros sus sentimientos hacia algo y además sabe que muchas otras personas están con ella en el mismo sentir. 


\section{La circulación del sentido y el afecto}

Como entorno de sentido, o semiosfera, la esfera pública aparece dotada de un centro, formado por los medios y discursos de grandes audiencias y por los lugares comunes obvios, incuestionados. Un centro que está siempre en tensión mayor o menor con una periferia formada por espacios comunicación e interacción de alcance restringido, que dinamiza, cuestiona, renueva esos sistemas de sentido dominantes (Lotman 1996). En la visión de Lotman, el dinamismo es privilegiado sobre el estatismo y éste se convierte en un momento especial de aquél, una interrupción del fluir continuo de las tradiciones y los códigos (como detienen el continuo cambio, por ejemplo, de las lenguas, las academias y las gramáticas al consolidar y consagrar ciertos cánones, en los periodos en que se busca la afirmación y el auto-conocimiento de una cultura). Esto nos lleva a preguntarnos cómo y por qué ciertos sistemas de sentido se estabilizan y refuerzan, cómo se detiene el flujo de diálogo y transformación de las formas expresivas y de los contenidos implicados. Y a observar los lugares comunes como lugares de conflicto, latente o efectivo, entre diferentes perspectivas y como sede de un dinamismo intrínseco a la vida de la semiosfera.

Observar la circulación, cambio y estabilización de los sistemas de sentido y de los lugares comunes es observar cómo se construyen los asuntos y el propio espacio de comunicación de lo público. Ciertos objetos de investigación semiótica parecen abrir particularmente esta posibilidad:

- La formación y transformación de las memorias, las enciclopedias, los imaginarios de que se sirven los receptores para dar sentido. Cada interpretación es una hipótesis del receptor, una conjetura sobre el sentido de algo, que realiza partiendo de su enciclopedia-memoria de textos, experiencias y encuentros anteriores. Nos interesa aquí enciclopedia semiótica -el conjunto de recursos simbólicos que nos permiten interpretar y construir sentido (Eco, 1990)-que interviene en los intercambios o procesos de semiosis particulares, que es siempre una enciclopedia parcial o local, correspondiente a una determinada comunidad interpretativa. No es posible describir en su totalidad esas enciclopedias locales, pero sabemos que contienen "las regularidades del saber medio (average knowledge) de una cultura dada, sus asunciones de fondo, en otras palabras, todo lo que es dado por descontado" (Violi 2017; Eco, 2007). Ese saber medio, o Enciclopedia Media, que los interlocutores de una comunicación presumen compartir es clave en esta indagación.

Podemos observar esas enciclopedias locales como recursos colectivos cristalizados en el uso, en los discursos y las interpretaciones. Unos recursos conocidos, que preceden al intercambio comunicativo, pero que también son transformados por los usos e intercambios. En el sentido de Eco y de Bajtin (1989), las lenguas y las enciclopedias están siempre haciéndose o rehaciéndose dialógicamente en los intercambios comunicativos. Cada enciclopedia y cada lengua (registro, variante, dialecto) se contamina y se transforma en su aproximación comunicativa a la lengua y la enciclopedia del otro, fundamento de toda comunicación. Se transforman junto con las formas de vida y los usos, que están insertos en prácticas sociales e implican las dimensiones afectivas, culturales, políticas, de la comunicación. El análisis del sentido, y en particular el de las enciclopedias parciales y de la forma en que estas in- 
tervienen, se discuten y transforman en las interacciones comunicativas, los textos y las controversias sobre los asuntos públicos, aparece así imbricado con la comprensión de las formas de vida, los mundos sociales, culturales y afectivos de los intérpretes. Podemos estudiar cómo participan esas enciclopedias, con sus supuestos de fondo e imaginarios, en las dinámicas en que se forma y transforma el sentido y el valor de los objetos y asuntos del mundo común. (Peñamarín, 2015).

- El espacio-tiempo del receptor y las comunidades interpretativas. Partiendo del supuesto de que toda comunicación y todo discurso prevé y anticipa la comprensión de un destinatario, cabe preguntarse cómo se conforma la figura del destinatario en el tiempo. La información de actualidad, de la que se ocupa el periodismo, está referida al ahora, indica deícticamente "esto ha sucedido". Conlleva un marchamo de realidad y dice, sin decirlo, "esto ha sucedido en tu mundo y te interesa, te afecta". Entre las incontables cosas que suceden en el mundo ¿por qué la información de la actualidad selecciona algo en particular? No sólo porque ocurre o es impactante, quizá sobre todo porque la situación actual, con sus actores y figuras relevantes, apunta a lo que eso puede traer, a la amenaza o la esperanza que encierra. Así la información de actualidad, en su ansiosa carrera por captar la disputada atención de los espectadores, nos presenta lo que "está pasando" desde la perspectiva de lo que va a pasar o lo que "nos" podría ocurrir si se acentúa, se consolida o se revierte, la actual situación. Es la potencialidad encerrada en el ahora lo que, según la información, nos interesa y afecta. Y afectarnos emocionalmente es, como he señalado, clave para la comunicación mediática.

El receptor puede quedar atrapado en esa tensión del presente que está siempre apuntando a algo inminente. Pero cuando pensamos en un asunto público cualquiera, comprendemos que el público cuenta sólo con retazos de informaciones e imágenes que apenas le permiten formarse una idea de lo que está en juego en tal asunto. El receptor ha de componer mentalmente el puzle de los fragmentos que sobre el asunto le han proporcionado los medios. Y en ese trabajo de composición se pueden producir efectos no previstos por el emisor. Como el hecho de que la imagen de grupos humanos desbordando las barcas en que viajan de África hacia Europa sea, por su extrañeza y dramatismo, enormemente atractiva para los espectadores y los medios, que hace que tal imagen se repita desde hace décadas en las portadas de nuestros informativos. Es esa imagen la que da un precario marco de sentido al asunto "inmigración". Todo el asunto queda definido desde esa imagen, siempre acompañada por informaciones limitadas al "llegan $\mathrm{X}$ número de inmigrantes" (o no consiguen llegar, o mueren en el intento...). Gracias a esa forma que adquiere el asunto al ser mediatizado, gran parte de la población tiene una percepción distorsionada sobre la inmigración, sobre el número de migrantes irregulares que llegan a nuestro país y sobre el peligro de "invasión" que ese continuo goteo de llegadas implicaría.

Si pensamos en colectividades de destinatarios que son receptores de los mismos textos (el público lector de los diferentes diarios, el espectador de los varios informativos de actualidad, el participante habitual de cierta red digital, por ejemplo) durante un tiempo largo, podemos preguntarnos cómo una sucesión o una serie continua de textos puede darnos pistas para entender 
la formación y consolidación de comunidades interpretativas y de sus respectivas enciclopedias (Violi, 2017). Aun sin entrar en los estudios dedicados específicamente a la recepción, podemos observar cómo esas interpretaciones se objetivan en la esfera pública, en las diferentes opiniones y valoraciones, en los lugares comunes manifestados en discursos y comportamientos públicos, así como en la forma en que los medios incorporan las preferencias, supuestos y valores de sus públicos.

- Los relatos o, más ampliamente, la dimensión narrativa del sentido, la orientación de valor y afecto inscrita en los discursos, que siempre que tratan de lo actual se abren a lo posible, lo deseable o lo temible para el destinatario previsto. Podemos servirnos del notable trabajo semiótico realizado en este campo para estudiar la dimensión narrativa del sentido de los asuntos públicos (Lorusso y Violi, 2004; Arquemboroug, 2015) en su orientación hacia los valores y afectos del destinatario, indagar cómo trata la narración, o la casi-narración informativa, de hacerle comprender y sentir de determinada manera lo que relata. O bien, cómo sugiere una apertura narrativa que no llega a cerrarse, a determinar un sentido pleno, por lo que suscita una demanda de nuevos relatos que permitan al receptor construir un sentido narrativamente cerrado (Lorusso y Violi, 2018). Entre estos recursos orientados a hacer sentir está implicada la imagen informativa, que no puede ser enteramente traducida a palabras, aunque es siempre mediada por ideas, fragmentos de relatos y expresiones verbales, así como la dimensión figurativa de los discursos, que introducen figuras y personajes que resultan atractivos o repulsivos, que apelan a la sensibilidad y a la identificación afectiva, ética o estética del destinatario.

- Las perspectivas de la enunciación. La puesta en perspectiva es infaltable en todo enunciado, dado que la definición, o el "retrato", de un objeto es correlativa a "la posición y los intereses del enunciador", por lo que su opción al elegir una de las definiciones o categorizaciones posibles produce siempre un "efecto de perspectiva", como señalan Fontanille y Zilberberg (2004: 22). Para aproximarnos al análisis de la polemicidad y la pluralidad de visiones implicadas en un asunto público, es preciso desarrollar este concepto de perspectiva. Así como el que propuso Mannheim (1993: 238), que define perspectiva como "la forma en que contemplamos un objeto, lo que percibimos de él, y cómo lo reconstruimos en nuestro pensamiento". Este vago concepto, que incluye la percepción, la visión y la construcción mental de un objeto, presenta la perspectiva como indisolublemente ligada a un sujeto. Aquí nos referimos a perspectivas colectivas y públicas, entendiendo que tales perspectivas son siempre "de alguien", implican sujetos colectivos, formas de vida, intereses y tramas socio-históricas de relaciones.

Gusfield sostiene que en torno a un problema público puede haber una perspectiva "propietaria", que define el issue en una forma que es aceptada como la definición de sentido común y hace irrelevantes o invisibles cualesquiera otras perspectivas. También para Lotman, como he mencionado, en una semiosfera hay un centro formado por los sistemas de sentido dominantes y una periferia que puede alterar o cuestionar esos sistemas dominantes. A ese ámbito de lo dado por descontado se refieren Roland Barhes, que habla de sistemas "naturalizados" con la obviedad de lo incontestable ("la verda- 
dera violencia es la de lo que se da por sentado" -Barthes 1997: 96), y Peirce (C.P. 5.265), que se refiere a aquellas convicciones que "no sabríamos cómo podrían ser cuestionadas".

La propia jerarquización de la EP evidencia esta frontera entre lo central y lo periférico. Una inabarcable multitud de actores individuales y colectivos interviene hoy a través de medios unidireccionales (de uno a muchos) y pluridireccionales (de muchos a muchos) en el archipiélago (Cefaï 2002) o enjambre de esferas públicas. Pero una frontera semiótica no es una pared inamovible, es el lugar del diálogo, el conflicto y la negociación entre los diferentes intereses, recursos y perspectivas que entran en juego. Así la frontera de la EP "oficial" o dominante suele ser cuestionada y desplazada en la pugna entre las diferentes perspectivas e intereses, aunque finalmente se tiende a reconstruir la diferencia centro-periferia y a estabilizar un ámbito de medios dominantes (los de grandes audiencias) y de lugares comunes mayoritariamente aceptados, una Enciclopedia Media, en términos de Eco. Sin embargo, como he apuntado, tanto los lugares comunes como los propios asuntos de la EP han de ser vistos siempre como lugares de diversidad y de potencial conflicto, donde la obviedad del lugar común refleja un proceso de estabilización y fijación que nunca destruye por completo la diversidad y polemicidad de la vida social del sentido.

\section{El bloqueo del sentido y las fronteras afectivas.}

Las lenguas, las perspectivas y las visiones del mundo, sostiene Bajtin (1989), se interpenetran, tanto en la conciencia individual como en la comunicación intersubjetiva, literaria o pública. Los estudios de orientación pragmática sobre la esfera pública (Cefaï, 2002) subrayan la actividad de muy diversos actores, medios, intereses y perspectivas, como si el diálogo, la discusión, la interinfluencia, estuvieran siempre presentes en la EP. Sin embargo, observamos que a menudo la comunicación pública sobre cierto asunto se bloquea, las varias perspectivas no dialogan sino que se encastillan en posiciones inamovibles desde las que ignoran o desprecian las visiones alternativas. Es fundamental preguntarse cómo se bloquean las diferentes visiones de un asunto, qué hace imposible el diálogo. En el estudio del dinamismo de los sistemas de sentido hay que tener en cuenta también la interrupción de ese dinamismo, el bloqueo, la formación de fronteras rígidas, por un tiempo inamovibles. En varias de las controversias públicas que estudiamos observamos este cierre. La controversia sobre prostitución, por ejemplo, está bloqueada en la incompatibilidad entre la posición abolicionista dominante y la posición pro trabajo sexual, marginada. El asunto clave de la inmigración, como he apuntado, es percibido desde una perspectiva dominante que impide toda discusión pública sobre posibles perspectivas alternativas.

En nuestra hipótesis las perspectivas sobre un objeto se bloquean en la dimensión afectivo-valorativa del sentido. En torno a la prostitución domina el campo discursivo el sentimiento de una de las partes, la abolicionista -la voz "propietaria" del asunto-, de ofensa moral ante un comportamiento que consideran injusto y degradante. Enfrente, más que a un adversario percibe a alguien que sostiene el abuso y la degradación de las mujeres, generalmente equiparando prostitución con esclavitud o "trata" (Saiz-Echezarreta, 2019). En el caso de la inmigración dominan el campo 
los sentimientos de autosatisfacción, extraneidad y de miedo ante unos otros que, debido a la forma que le da la mediatización del asunto, se perciben como extraños e invasivos. Lo dominan al punto que los discursos alternativos apenas se atreven a expresarse abiertamente en la arena pública (los políticos de izquierdas eluden pronunciarse sobre este asunto, que consideran hoy siempre favorable a la ultraderecha). Sobre la inmigración hay también un importante caudal de conocimiento científico y especializado que proyecta visiones muy diferentes a las que dominan esa percepción común. Pero ese conocimiento, aunque es ocasionalmente recogido o mencionado en los medios informativos, carece de influencia en el modo como los públicos valoran y sienten esta cuestión, bloqueado por el predominio de sentimientos de temor y rechazo que no llegan a ser reconocidos, explicitados y elaborados en la comunicación pública.

Estas fronteras afectivas nos remiten de nuevo a Lotman (1996), que, recordemos, pone el drama shakespeariano Romeo y Julieta como ejemplo del mecanismo de frontera en la semiosfera. Los Capuleto y los Montesco son familias que pertenecen a la misma época y lugar, tienen la misma cultura y unas enciclopedias muy similares. Sin embargo, no se hablan. Les separa una frontera de odio y rencores, una frontera afectiva hecha de memorias e historias de familia que siguen doliendo en el tiempo ahora. El sujeto que se bloquea en una posición se niega a perder o cuestionar algo que le resulta fundamental; su comportamiento muestra que un objeto de valor se ha convertido en irrenunciable. Este tipo de valor surge cuando "uno ya no puede prescindir" de algo (Latour 2013: 409) y se distingue de otros valores porque no es intercambiable. "Si hay algo que no puede reducirse a una transferencia de equivalentes, es precisamente la irrupción del valor" (2013: 415). Según Latour, esta perspectiva nos llevaría a esquivar esa filosofía (de la identidad, de la esencia) que "nos habría obligado a no confesar nunca nuestro apego a las cosas capaces de darnos propiedades que no sabíamos que poseíamos" (2013: 406).

Pero ese tipo de valor tan irrenunciable para el sujeto que a menudo éste no lo distingue de sí mismo, estaba ya presupuesto en Aristóteles. Cuando, en la Retórica, comienza su estudio sobre las pasiones por la ira, dice: "Admitamos que la ira es un apetito penoso de venganza por causa de un desprecio manifestado contra uno mismo o contra los que nos son próximos". Una persona se encoleriza "por algo que le han hecho o iban a hacerle a él mismo o a los suyos" (1990: 309-313). La ira surge en un cuerpo tanto por un desprecio que le hacen al propio sujeto, como "a los suyos", los que le "son próximos". Estos forman parte de él al punto de que le afectan en carne propia las ofensas hacia ellos. Pero tal apego no se restringe al vínculo con otros humanos, ya que las personas también se encolerizan contra los que "hablan mal y muestran desdén hacia las cosas por las que ellos se interesan especialmente”, como, por ejemplo, "ocurre con los que ponen toda su ambición en la filosofía, si alguien (habla) en contra de la filosofía; o con los que la ponen en el aspecto personal, si alguno (desdeña) la buena presencia; y de modo semejante en los demás casos". (1990: 318) Según este agudo observador, la reacción airada de esas personas muestra que sienten tales objetos, la filosofía o la elegancia, como parte de sí mismas, como algo que no se puede despreciar sin despreciar a la propia persona.

Además de señalar la cuestión fundamental de este tipo de valor irrenunciable, Latour añade las "propiedades" que el objeto de apego da al sujeto, que éste no podía haber previsto. Podemos entender esta aportación del sentirse apegado a través de su pérdida. El apego hacia una persona o un objeto, hacia la propia localidad o país, 
a menudo se evidencia con particular intensidad cuando se pierde. Quizá porque al perderla descubrimos que esa parte ahora desaparecida nos daba algo, unas "propiedades", que nos pasaban tan desapercibidas como el aire que respiramos (imperceptible justamente hasta que se enrarece o se hace tóxico, momento en que pasamos a verlo como algo básico, imprescindible para nuestra vida).

Es preciso considerar las fronteras afectivo simbólicas y territoriales que impiden la comunicación sobre ciertos asuntos en el EP. Deleuze y Guattari (1991: 66) insisten en los procesos de hacer y deshacer territorio, mostrando que tales vínculos, aunque sean vividos como irrenunciables, no son esenciales o inamovibles. Lo que sí parece central en los animales territoriales y en los humanos es la necesidad en cada momento de dotarse de un territorio propio, de vincularse y sentirse parte de algo.

La dificultad que presentan las controversias bloqueadas es la de reconocer ese vínculo afectivo con un objeto que da valor y "propiedades" al propio sujeto y que éste no acepta perder. En el caso de la prostitución, he señalado cómo la posición abolicionista no puede no rechazar e incluso despreciar a quienes ve como ofensores de la dignidad humana básica. El sentir esa ofensa es algo que hace valiosa, a sus ojos, a la propia persona, que se percibe así como dotada de altos y firmes valores morales.

Pero todos los valores implican algún tipo de vínculo afectivo. En las imágenes de las enormes vallas que en Ceuta y Melilla tratan de contener la entrada de migrantes, vemos la no-violencia de los guardias españoles que impiden que los migrantes consigan pasar la valla. No soportaríamos las imágenes de esas personas siendo apaleadas, heridas o muertas por "nuestras" fuerzas. Está ahí nuestro umbral, nuestra frontera moral ante el valor sentido como propio: cualquier humano merece la no-violencia, sobre todo de una fuerza superior y armada. Situarnos ante el acto de sobrepasar ese límite nos resulta inaceptable, porque afecta a nuestra imagen de nosotros mismos y al juicio que creemos merecer. Ver esa imagen de violencia implicaría vernos como agentes, como causantes de la acción lesiva. Como reveló Bauman respecto al holocausto nazi, la racionalidad moderna opera así. Las acciones -aquí vigilar una valla, pedir documentos en la frontera, expulsar a quienes no tienen los documentos en regla- están separadas y organizadas como independientes entre sí y aparentemente desvinculadas de su finalidad. De este modo, quienes realizan y quienes perciben esas acciones no las unen en una acción total con sus consecuencias y evitan el impulso y la evaluación moral (Baumann, 1997; 2004).

Restituir el punto de vista del receptor implica tener en cuenta el "montaje" que éste ha de realizar, a partir de fragmentos en principio inconexos, en su actividad interpretativa. Abril (2003) señala la peculiar modernidad de la práctica periodística que "arranca las cosas de sus contextos" y exige del receptor una "actitud errática y dispersa, una lectura indicial más que convencional, el aprendizaje más incidental que formalizado de los objetos de interés". El receptor ha de organizar el sentido de los asuntos que le interesan "por acúmulos de fragmentos que se agrupan y se desagrupan" a menudo de modos nefandos. Así están netamente separadas en nuestra percepción, por la restricción de los puntos de vista, la muerte de quienes tratan de entrar al país y la frontera que les bloquea la entrada. Pero las sucesivas imágenes de barcas desbordadas por personas de color que acuden a nuestras costas se acumulan en el montaje que realiza el receptor como si fueran la clave del sentido del asunto "inmigración". Ese precario marco de sentido que puede componer el receptor a partir de la cadena aparentemente interminable de llegadas de grupos de inmigrantes 
no cierra una narración con sentido (llegan, son acogidos y ¿qué ocurre finalmente con ellos? ¿se quedan en el país, son definitivamente expulsados?). Esa inquietante apertura narrativa suscita la búsqueda de una historia que permita al receptor llenar de sentido lo que permanece incierto. Un relato que sí proporcionan los discursos de la ultraderecha que promueven el temor, el rechazo abierto y la rabia por las políticas aparentemente no definidas y timoratas respecto a la inmigración.

Gracias a la comunicación continuada de cada medio con su público, al feedback permanente entre ambos polos de la comunicación, el enunciador incorpora en sus discursos el punto de vista de su destinatario. Podemos así estudiar las formas de mediatización de los asuntos y las condiciones que crean para la comprensión de los públicos y observar los sentimientos, expectativas y supuestos con que cuenta el enunciador para producir su comunicación. Un estudio que puede contribuir tanto a la discusión y elaboración de los problemas comunes, como a la ampliación de los puntos de vista, una tarea fundamental para los medios de comunicación y para quienes se interesan por la construcción del mundo común.

\section{Bibliografía}

Ahmed, S. (2004) The cultural politics of emotion. Edimburgo: Edimburg University Press. Álvarez-Peralta, M. (2014): "La crisis estructural del periodismo en España", El viejo topo, 322, [http://www.elviejotopo.com/web/revistas.php?numRevista=322,

Arendt, H. (1997) ¿Qué es la política?, Barcelona: Paidós.

Arendt, H. (1993) La condición humana. Barcelona, Paidós

Aristóteles, (1990) Retórica. Madrid, Gredos.

Arquembourg, J. (2015) "Los retos políticos de los relatos de la información" en R. Rodríguez y V. Tur-Viñes (Coords.) Narraciones sin fronteras. Cuadernos Artesanos de Comunicación / 81.

Arsenault, A. Y Castells, M. (2006) "Conquering the minds, conquering Iraq: The social production of misinformation in the United States - a case study", Information, Сотmunication and Society, Vol. 9, N. 3.

Bajtin, M. M. (1989) Teoría y estética de la novela, Madrid, Taurus.

Barthes, R. (1997) Barthes por Barthes. Caracas, Monte Ávila.

Bauman, Z. (1997) Modernidad y holocausto, Madrid, Sequitur.

Bauman, Z. (2004) Ética posmoderna, Buenos Aires, Siglo veintiuno editores Argentina.

Beckett, C., \& Deuze, M. (2016). On the Role of Emotion in the Future of Journalism. Social Media + Society, Volume: 2 issue:3. 1-6 https://doi.org/10.1177/2056305116662395

Belting, H. (2015) "Imagen, medium, cuerpo: un nuevo acercamiento a la iconología", CIC Cuadernos de Información y Comunicación, vol. 20 (153-170)

Butler, J. (2006) Vida precaria. El poder del duelo y la violencia. Buenos Aires, Paidós

Castañares, W. (2019) "Filosofía pragmática y lógica de la representación-mediación", en Barrena, S. y Nubiola, J. (eds), Escritos sobre C. S. Peirce. Wenceslao Castañares. Pamplona, EUNSA.

Castells, M. (2008) "The New Public Sphere: Global Civil Society, Communication Networks, and Global Governance", ANNALS, AAPSS, 616.

Cefaï, D. (2002). «Qu'est-ce qu'une arène publique? Quelques pistes pour une approche pragmatiste». En Cefaï, D. y Joseph, I. (coords.). L'heritage du pragmatisme. Conflits 
d'urbanité et épreuves de civisme. La Tour d'Aigues: Éditions de l'Aube

Damasio, A. (2006). En busca de Spinoza. Neurobiología de la emoción y los sentimientos. Barcelona, Crítica.

Deleuze, G. Guattari, F. (1991) Qu'est que la philosophie? Paris, Minuit.

Eco, U. (2007) Dall'albero al labirinto. Studi storici sul segno e l'interpretazione, Milán, Bompiani.

Eco, U. (1990) Semiótica y filosofía del lenguaje. Barcelona: Lumen.

Elias, N. (2009). El proceso de la civilización. México, Fondo de Cultura Económica.

Escudero, L. (1996). Malvinas: el gran relato. Fuentes y rumores en la información de guerra. Barcelona: Gedisa.

Fontanille, J. y Zilberberg, C. (2004). Tensión y significación, Universidad de Lima, Fondo de Desarrollo Editorial.

Gitlin, T. (2013), "Un cúmulo de crisis: circulación, ingresos, atención, autoridad y confianza”, CIC. Cuadernos de Información y Comunicación, vol. 18, pp. 11-23.

Gould, D. (2009). Moving Politics. Emotion and ACT UP's Fight against AIDS. Chicago y Londres: The University of Chicago Press.

Gross, D. M. (2006) The Secret History of Emotion. From Aristotle's "Rhetoric » to Modern Brain Science. Chicago and London, The University of Chicago Press

Gusfield, J. (1981), The culture of public problems. Chicago, Chicago University press

Hochschild, A. (1990). "Ideology and Emotion Management: A Perspective and Path for Future Research", en Kemper, T. D. (ed). Research Agendas in The Sociology Of Emotions. Albany: State University of New York Press, 117-142.

Lakoff, G. (2007). No pienses en un elefante. Lenguaje y debate político. Madrid. Editorial Complutense.

Latour, B. (2013) Investigation sobre los modos de existencia, Barcelona, Paidós.

Latour, B. (1991) "On Technical mediation. Philosophy, Sociology, Genealogy”, Common Knowledge, FaIl 1991 V. 3 N. 2

Leys, R. (2011), “The Turn to Affect: A Critique”. Critical Inquiry, 37

Lorusso A. M. y Violi, P. (2018) "Los controvertidos límites de la visibilidad: el caso Aylan”, en Álvarez-Peralta, G. Fernández y L. Mazzoli (eds.) La mediación fragmentaria. Mediatización y controversia en la nueva esfera pública, Cuadernos Artesanos de Comunicación / 132. http://www.cuadernosartesanos.org/2017/cac132.pdf

Lorusso A. M. y Violi, P. (2004). Semiotica del testo giornalistico. Bari: Laterza.

Lotman, I. (1996), La semiosfera I. Valencia: Frónesis-Cátedra

Lünenborg, M. \& Maier, T. (2018)." The Turn to Affect and Emotion in Media Studies". Media and Communication 1-4. DOI: 10.17645/mac.v6i3.1732

Macón, C. y Solana, M. (2015). “Introducción”, en Macón, C. y Solana, M. (eds.) Pretérito Indefinido. Afectos y emociones en las aproximaciones al pasado. Buenos Aires, Recursos Editoriales.

Mannheim, K. (1993) Ideología y utopía. Introducción a la sociología del conocimiento. México, Fondo de Cultura Económica.

Miller, W. I. (1998). Anatomía del asco. Madrid. Santillana

Peñamarín, C. (2018) "Mediación y mediatización de la comunicación pública. Una perspectiva pragmática”, en M. Álvarez-Peralta, G. Fernández y L. Mazzoli (eds.) La mediación fragmentaria. Mediatización y controversia en la nueva esfera pública, Cuadernos Artesanos de Comunicación / 132. http://www.cuadernosartesanos.org/2017/cac132.pdf

Peñamarín, C. (2016). "La elaboración de pasiones y conflictos en la nueva esfera pública", DeSignis, 24. 
Peñamarín, C. (2015) “Creatività e trasformazione culturale. Il dinamismo dei sistemi di significazione”, Versus. Quaderni di studi semiotici, 212, pp: 53-69.

Peñamarín, C. (2014). "Esfera pública y construcción del mundo común. El relato dislocado", CIC. Cuadernos de Información y Comunicación, vol. 19, pp. 103-124.

Peirce, C. S. (1994) C.P. The Collected Papers of Charles Sanders Peirce, vols. I-VIII, Electronic Edition

Reckwitz, A. (2017). "Practices and their affects". In A. Hui,T. Schatzki, \& E. Shove (Eds.), The nexus of practices. Abingdon: Routledge.114-125

Rosenwein, B. H. (2006). Emotional Communities in the Middle Ages. Ithaca: Cornell University Press.

Saiz-Echezarreta, V. (2019). "Mediatización de las controversias públicas: a propósito de la campaña sobre prostitución Hola Putero", Revista Mediterránea de Comunicación/ Mediterranean Journal of Communication, 10(1), 95-115. https:/www.doi.org/10.14198/ MEDCOM2019.10.1.19

Simondon, G. (2015): La individuación: a la luz de las nociones de forma y de información. Buenos Aires. La Cebra/Cactus ( $2^{\mathrm{a}}$ ed.)

Violi, P. (2017) "Encyclopedia: criticality and actuality", Illinois, The Library of the Living Philosophers, Open Court Publishing Company of La Salle.

Williams, R. (1977). Marxism and literature. Oxford: Oxford University Press. 